\title{
Liver Transplantation in a Patient with Absent Inferior Vena Cava: Case Report
}

\author{
İnferior Vena Cava Bulunmayan Bir Hastada Karaciğer Transplantasyonu: Olgu Sunumu
}

\author{
Ramazan DÖNMEZ ${ }^{1}$ \\ (D) 0000-0003-2455-6380 \\ Ahmet KARGI ${ }^{2}$ \\ (D) 0000-0002-9989-7940 \\ Şerafettin YAZAR ${ }^{2}$ \\ (i) 0000-0002-1911-6746 \\ Serdar ASLAN ${ }^{2}$ \\ (1) 0000-0002-6891-1615 \\ Kemal PEKER ${ }^{3}$ \\ (D) 0000-0001-5907-0466 \\ Kamil Yalçın POLAT ${ }^{2}$ \\ (D) 0000-0002-2840-2429
}

\begin{abstract}
${ }^{1}$ Yeditepe University Faculty of Medicine Department of General Surgery, İstanbul, Turkey

${ }^{2}$ Bahçelievler Memorial Hospital Department of General Surgery, İstanbul, Turkey
\end{abstract}

${ }^{3}$ Düzce University Faculty of Medicine Department of General Surgery, Düzce, Turkey

\section{Corresponding Author Sorumlu Yazar \\ Kemal PEKER \\ k.peker@yahoo.com.tr}

Received / Geliş Tarihi : 23.01.2020 Accepted / Kabul Tarihi : 29.03.2020 Available Online /

Çevrimiçi Yayın Tarihi : 25.04.2020

\begin{abstract}
Transplantation procedure used if the recipient and donor do not have a special anatomical variation today; left lateral segment in the pediatric age group, and right lobe in the adult age group. Biliary atresia in children and various liver diseases like metabolic events in adults are the major causes of liver transplantation. Liver transplantation is challenging in the patients with congenital vascular anomalies. Infrahepatic interruption of the inferior vena cava (IVC) is a rare congenital anomaly with the incidence of $0.6 \%$ to $2 \%$ and mostly found with congenital heart disease. In this study we tried to report a 58 -year old male patient with a diagnosis of decompensated liver cirrhosis caused by the hepatitis B virus (HBV) who was hospitalized for the first time for living donor liver transplantation.
\end{abstract}

Keywords: Liver transplantation; inferior vena cava (IVC); congenital anomalies.

\section{ÖZ}

Günümüzde alıcı ve vericinin özel anatomik bir varyasyonunun yokluğunda kullanılan transplantasyon prosedürü; pediatrik yaş grubu için sol lateral segmentin alınması, erişkin yaş grubunda ise sağ lobun kullanılmasıdır. Çocuklarda biliyer atrezi, erişkinlerde ise metabolik olaylar gibi çeşitli karaciğer hastalıkları karaciğer transplantasyonu için başlıca nedenlerdir. Karaciğer transplantasyonu, konjenital damar anomalisi olan hastalar için oldukça zor bir işlemdir. İnferior vena cavadaki, infrahepatik kesinti \%0,6 ile \%2 oranında gerçekleşen oldukça nadir bir konjetinal anomalidir ve genellikle konjenital kalp hastalığı ile birlikte görülür. Biz bu çalışmada, hepatit B virüsü (HBV) zemininde gelişen dekompanse karaciğer yetmezliği tanısı olan ve canlı vericiden karaciğer nakli için ilk kez hastaneye yatışı yapılan 58 yaşındaki erkek hastayı takdim etmek istedik.

Anahtar kelimeler: Karaciğer transplantasyonu; inferior vena cava (IVC); konjenital anomaliler.

\section{INTRODUCTION}

Infrahepatic interruption of the inferior vena cava (IVC) with azygos or hemiazygos substitution has been reported generally in children (1). Infrahepatic interruption of the IVC is a rare congenital anomaly with the incidence of $0.6 \%$ to $2 \%$ and mostly found with congenital heart disease (2). Although liver transplantation (LT) in children with biliary atresia and polysplenia syndrome accompanying IVC anomalies have been routinely performed, to the best of our knowledge only one single deceased donor LT in an adult patient with developmental interruption of the IVC with hemiazygos substitution was reported. In this study we report for the first time a living donor liver transplantation (LDLT) in an adult patient with developmental interruption of the IVC with hemiazygos substitution and its' technical details. 


\section{CASE REPORT}

A 58-year old male patient with a diagnosis of decompensated liver cirrhosis caused by the hepatitis B virus (HBV) was hospitalized for LT. Physical examination revealed splenomegaly and atrophic liver with ascites. MELD point was 15. Abdominal computed tomography (CT) showed atrophic and cirrhotic liver, interruption of the IVC with hemiazygos substitution (Figure 1).

An LDLT from his daughter was planned. At the laparotomy a diffuse nodular and atrophic liver with ascites was observed. After the liver was liberalized from its ligaments the developmental interruption of the IVC with hemiazygos substitution was observed. The hepatic veins were draining into the right atrium at the suprahepatic level. The donor hepatectomy was performed with a $990 \mathrm{gr}$ of the right liver graft with the $4 \mathrm{~mm}$ and 5 mm veins draining the segment $V, 7 \mathrm{~mm}$ vein draining the segment VIII and $10 \mathrm{~mm}$ size inferior hepatic vein. The drainages of the segments V, VIII and inferior hepatic vein were performed with the implant of cadaveric iliac arteries into the $10 \mathrm{~cm}$ segment of the cadaveric aortic graft at the back-table (Figure 2).

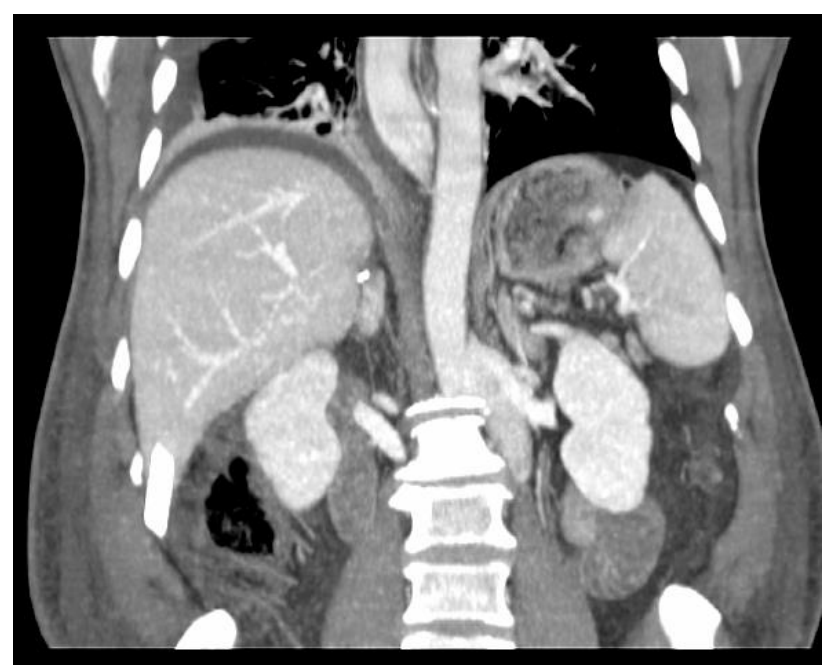

Figure 1. Transposition of Inferior Vena Cava prior to operation is shown in figure

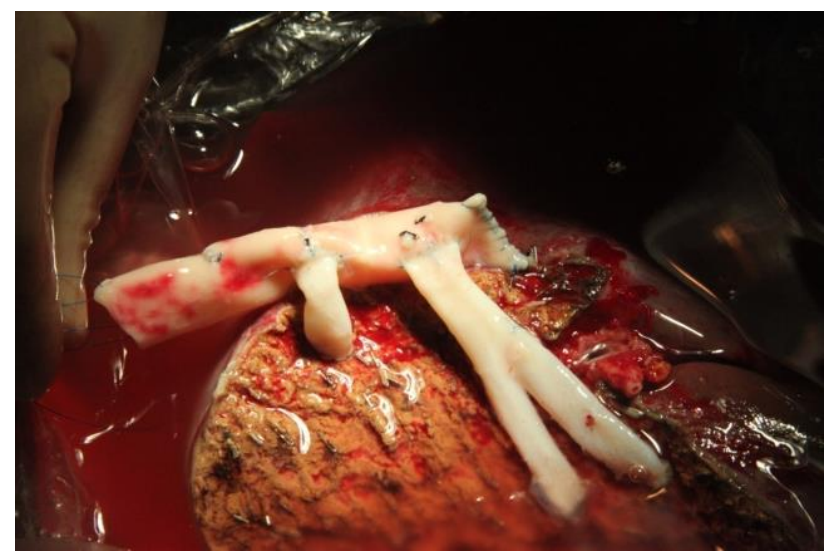

Figure 2. Liver drained with aortic graft and iliac grafts in back-table procedure and liver tissue in pre-transplantation phase with $5^{\text {th }}$ and $8^{\text {th }}$ segments are shown.
The inferior opening of the aortic graft was closed and the LT was completed (Figure 3).

Post treatment course of the patient was uneventful and he was discharged at post-transplant day 14. In his 6-months post treatment follow-up, liver is functioning well without any complication (Figure 4).

The patient was informed and consent was taken for the case report.

\section{DISCUSSION}

Systemic anomalous venous return is a heterogeneous group of vascular malformation in terms of clinical and anatomical (3). These anomalies may arise out of numerous variations of four main veins which are superior vena cava (SVC), IVC, vena azygos and hepatic veins (4). Interruption of IVC but continuity of venous return through vena azygos usually accompanies other cardiac congenital anomalies; it is rare to be seen as isolated congenital vascular anomaly (5).

According to its embryological origin, three pairs of fetal veins are formed with fusion, regression and mid-section anastomosis of system in $6^{\text {th }}$ to $8^{\text {th }}$ week of IVC gestation.

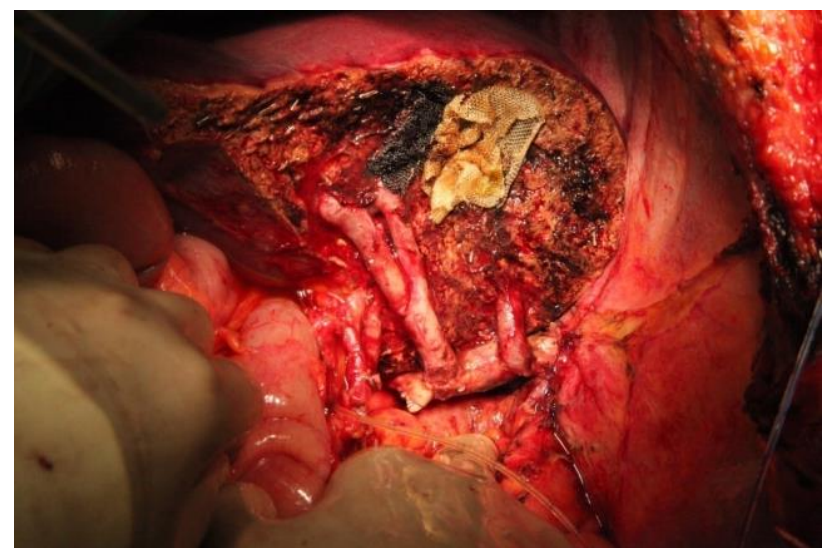

Figure 3. Transplanted liver and grafts after perfusion are shown in figure

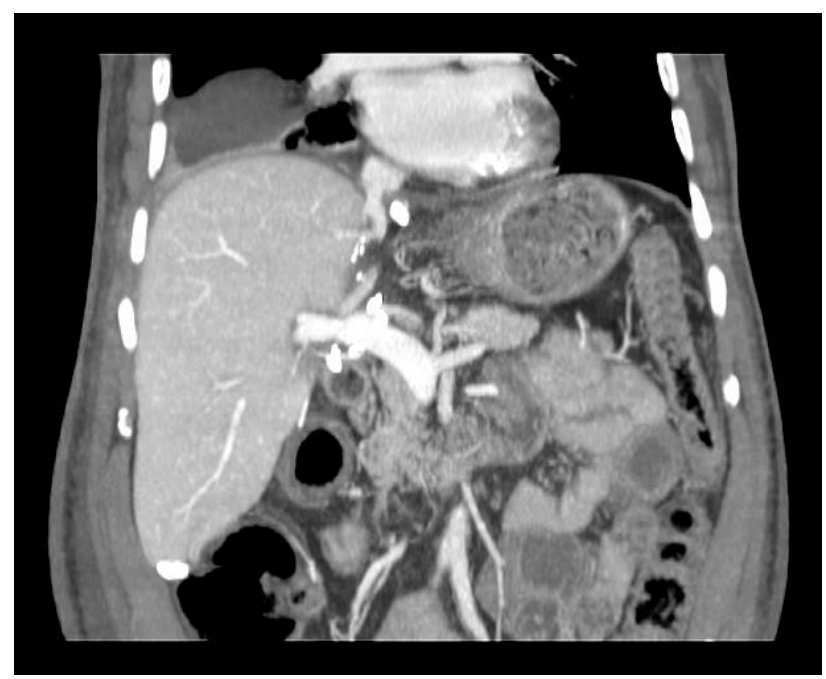

Figure 4. Abdominal CT image of patient having applied LT procedure and completed Inferior Vena Cava transposition 
Those veins contain two posterior, two sub-cardinal and two supra-cardinal veins. According to its embryological origin, IVC is consisted of four segments as hepatic, prerenal, renal and postrenal. The most frequent anomaly is the lack of infrahepatic segment of IVC and its drainage into the right atrium or SVC through azygos $(4,6)$. According to Chuang et al. (7), normal IVC is developed with an open right supra-cardinal vein and regression of the left one (type B). Exact opposite situation of that is resulted with transposed IVC (type C). Continuity of both supra-cardinal vein openings means duplication of IVC (type B, C). Most of IVC anomalies are asymptomatic. However, there is cyanoses in anomalies where IVC is drained into left atrium, besides that in anomalies caused due to lack of infrarenal segment of IVC, relapsing deep vein thrombosis in sub-extremities may cause bilateral venous failure $(5,8)$.

The only effective treatment of end stage liver failure is LT. LT from live donors is widespread in many countries like Turkey in which there are some difficulties about obtaining organs from cadavers. Compared to cadaveric liver transplantation; it has superiorities like effective operation opportunity for patients, lesser graft ischemia periods and eliminating waiting-list deaths (9). Donors and receivers having IVC anomalies may be appropriate patients for transplantation surgery (10). However, it is important to diagnose existing anomalies of this kind of patients prior to operation and plan the surgery to be held according to this situation (11). As a result, although it is obvious that transplantation surgeons may encounter these kinds of cases, we think that the surgical procedures defined in this case may be a guide for this type of patients.

\section{REFERENCES}

1. Zinser MJ, Hanto DW. Liver transplantation in a patient with developmental interruption of the inferior vena cava with azygos substitution. Transplant Proc. 2012:44(5);1460-3.
2. Trubac R, Hribernik M, Pac L. Congenital interruption of the inferior vena cava with hemiazygos continuation. Scripta Medica. 2002;75(6):291-302.

3. Tacy TA, Silverman NH. Systemic venous abnormalities: embryologic and echocardiographic considerations. Echocardiography. 2001;18(5):401-13.

4. Huhta JC, Smallhorn JF, Macartney FJ, Anderson RH, de Leval M. Cross-sectional echocardiographic diagnosis of systemic venous return. $\mathrm{Br}$ Heart J. 1982;48(4):388-403.

5. Vijayvergiya R, Bhat MN, Kumar RM, Vivekanand $\mathrm{SG}$, Grover A. Azygos continuation of interrupted inferior vena cava in association with sick sinus syndrome. Heart. 2005;91(4):e26.

6. Loukas M, Strike DRG, Tubbs RS, Tarneja N, Shoja MM. An interrupted inferior vena cava in a situs inversus: Case report and review of the literature. Folia Morphol (Warsz). 2009;68(3):184-7.

7. Chuang VP, Mena CE, Hoskins PA. Congenital anomalies of the inferior vena cava. Review of embryogenesis and presentation of a simplified classification. Br J Radiol. 1974;47(556):206-13.

8. Koc Z, Ulusan S, Oguzkurt L, Serin E. Symptomatic interrupted inferior vena cava: report of a case presenting with haematochezia. $\mathrm{Br} \mathrm{J}$ Radiol. 2007;80(954):e122-4.

9. Kasahara M, Egawa H, Takada Y, Oike F, Sakamoto $\mathrm{S}$, Kiuchi T, et al. Biliary reconstruction in right lobe living-donor liver transplantation: Comparison of different techniques in 321 recipients. Annals Surg. 2006;243(4):559-66.

10. Levi Sandri GB, Lai Q, Nudo F, Rossi M. Inferior vena cava interruption in a liver transplantation deceased donor. Liver Int. 2013;33(4):647.

11. Coelho JCU, Ramos EJB, da Costa MAR, Junior AP, Ivantes CAP. Liver transplantation in a patient with complex anomaly of the inferior vena cava. Hepatobiliary Surg Nutr. 2014;3(4):212-5. 